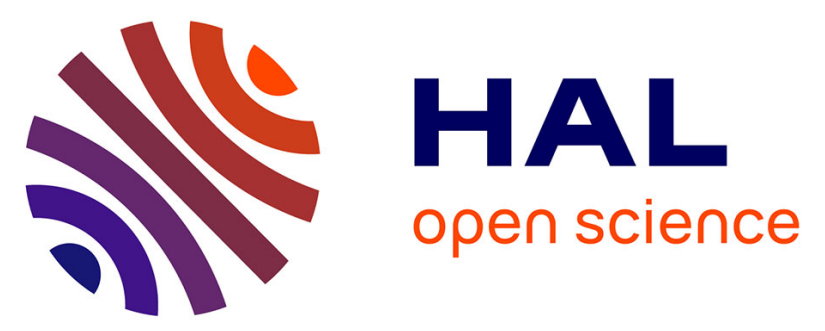

\title{
Comparison of three template preparation methods for routine detection of beak and feather disease virus and avian polyomavirus with single and nested PCR in clinical specimens
}

Oldrich Tomasek, Oldrich Kubicek, Viktor Tukac

\section{To cite this version:}

Oldrich Tomasek, Oldrich Kubicek, Viktor Tukac. Comparison of three template preparation methods for routine detection of beak and feather disease virus and avian polyomavirus with single and nested PCR in clinical specimens. Avian Pathology, 2008, 37 (02), pp.145-149. 10.1080/03079450801902047. hal-00540110

\author{
HAL Id: hal-00540110 \\ https://hal.science/hal-00540110
}

Submitted on 26 Nov 2010

HAL is a multi-disciplinary open access archive for the deposit and dissemination of scientific research documents, whether they are published or not. The documents may come from teaching and research institutions in France or abroad, or from public or private research centers.
L'archive ouverte pluridisciplinaire HAL, est destinée au dépôt et à la diffusion de documents scientifiques de niveau recherche, publiés ou non, émanant des établissements d'enseignement et de recherche français ou étrangers, des laboratoires publics ou privés. 


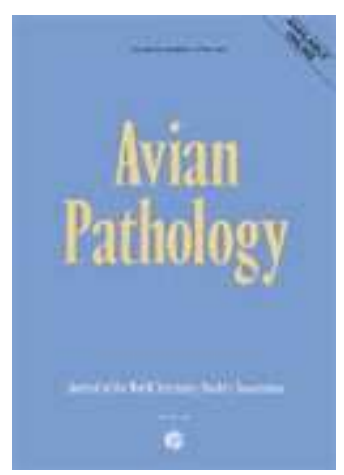

\section{Comparison of three template preparation methods for routine detection of beak and feather disease virus and avian polyomavirus with single and nested PCR in clinical specimens}

\begin{tabular}{|c|c|}
\hline Journal: & Avian Pathology \\
\hline Manuscript ID: & CAVP-2007-0100.R2 \\
\hline Manuscript Type: & Original Research Paper \\
\hline $\begin{array}{l}\text { Date Submitted by the } \\
\text { Author: }\end{array}$ & 23-Nov-2007 \\
\hline Complete List of Authors: & $\begin{array}{l}\text { Tomasek, Oldrich; University of Veterinary and Pharmaceutical } \\
\text { Sciences Brno, Avian and Exotic Animal Clinic } \\
\text { Kubicek, Oldrich; National Institute for Nuclear, Chemical and } \\
\text { Biological Protection } \\
\text { Tukac, Viktor; University of Veterinary and Pharmaceutical Sciences } \\
\text { Brno, Avian and Exotic Animal Clinic }\end{array}$ \\
\hline Keywords: & APV, budgerigar fledgling disease, DNA isolation, PBFD \\
\hline \multicolumn{2}{|c|}{$\begin{array}{l}\text { Note: The following files were submitted by the author for peer review, but cannot be converted } \\
\text { to PDF. You must view these files (e.g. movies) online. }\end{array}$} \\
\hline \multicolumn{2}{|c|}{ Backup of cavp-2007- 0100 style edited.wbk } \\
\hline
\end{tabular}

\section{SCHOLARONE \\ Manuscripts}




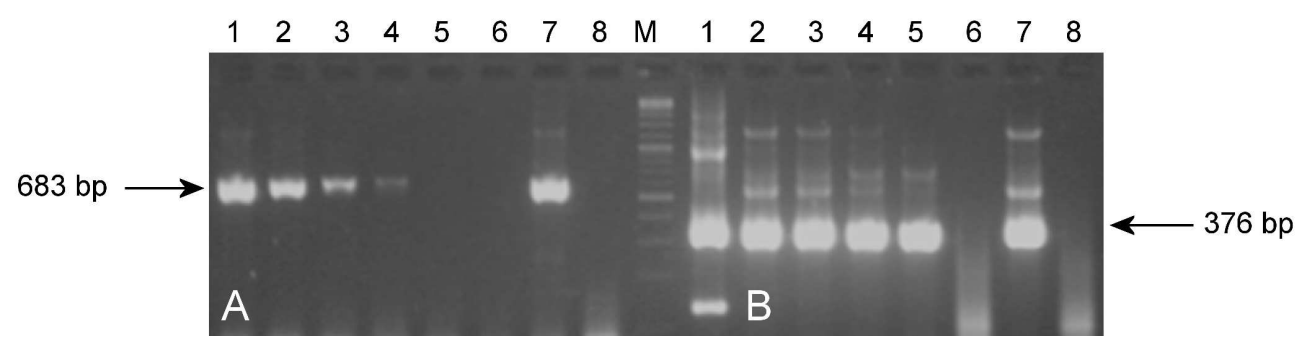

Figure 1

Limits of single PCR (A) and nested PCR (B) detection of APV DNA tested with serial 10-fold dilutions of template DNA. Lanes 1 to 6,104 to 10-1 copies/ $\mu \mathrm{L}$ of template DNA. Lane 7, positive control; lane 8 , negative control; $M$, weight marker. 